\title{
Evaluation of Knowledge and Compliance of Nurses on The Use Personal Protective Equipment (PPE) in Intensive Care Unit (ICU) RSUD Panembahan Senopati Bantul Yogyakarta
}

\author{
Ayu Cahyaningsih* \\ *Correspondent Author: Ayucahayaning@umy.ac.id \\ *Master of Hospital Management, Universitas Muhammadiyah Yogyakarta, Indonesia
}

\begin{tabular}{l}
\hline I N D E X I N G \\
\hline Keywords: \\
Evaluation; \\
Knowledge; \\
Compliance; \\
Nurses; \\
Personal Protective- \\
Equipment (PPE)
\end{tabular}

\begin{abstract}
A B S T R A C T
The purpose of this study is to evaluate the knowledge and compliance of nurses on the use of Personal Protective Equipment (PPE). This research use mix method research with descriptive survey approach and cross sectional design. Quantitative data were obtained from distributing questionnaires with total sampling techniques. Qualitative data obtained from observation and interview. The results of this study found that as many as 12 people nurses $(60 \%)$ have high knowledge and 8 people nurses $(40 \%)$ have low knowledge. Besides that, it was found that 16 nurses $(80 \%)$ were obeyed with the use of Personal Protective Equipment (APD) and 4 nurses (20\%) were disobey in the use of Personal Protective Equipment (PPE). The conclusion of this research is nurses at Intensive Care Unit (ICU) of RSUD Panembahan Senopati Bantul have high level of knowledge about Personal Protective Equipment (PPE) and they are obey on the use of Personal Protective Equipment (PPE).
\end{abstract}

\begin{abstract}
Kata Kunci:
Evaluasi;

Pengetahuan;

Kepatuhan;

Perawat;

Alat Pelindung Diri

(APD)

Tujuan penelitian ini adalah mengevaluasi pengetahuan dan kepatuhan perawat terhadap penggunaan Alat Pelindung Diri (APD). Penelitian ini menggunakan metode penelitian mix method dengan pendekatan survey deskriptif dan rancangan cross sectional. Data kuantitatif didapatkan dari membagikan kuesioner dengan teknik total sampling. Data kualitatif diperoleh dari observasi dan wawancara. Hasil penelitian ini diperoleh bahwa sebanyak 12 orang perawat (60\%) mempunyai pengetahuan tinggi dan 8 orang perawat (40\%) mempunyai pengetahuan rendah. Selain itu didapatkan bahwa sebanyak 16 orang perawat (80\%) Patuh terdapat penggunaan Alat Pelindung Diri (APD) dan 4 orang perawat (20\%) Tidak Patuh dalam penggunaan Alat Pelindung Diri (APD). Kesimpulan penelitian ini adalah tenaga perawat di Intensive Care Unit (ICU) RSUD Panembahan Senopati Bantul mempunyai tingkat pengetahuan mengenai Alat Pelindung Diri (APD) yang tinggi dan patuh terdapat penggunaan Alat Pelindung Diri (APD).
\end{abstract}

(C) 2017 JMMR. All rights reserved

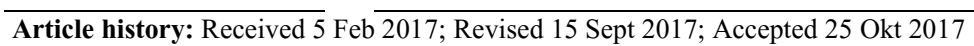

\section{INTRODUCTION}

Personal Protective Equipment (PPE) is a special clothing or equipment used for the protection of infectious substances. Personal Protective Equipment is very important for nurses. The work done by the nurse has high potential in the spread of infection, such as cleaning of body fluids, injection / blood collection, catheter installation, wound care, and others. If the work is not equipped with Personal Protective Equipment (PPE) in accordance with established procedures, will potentially transmit infectious diseases for both patients and health workers. $^{1}$

The use of PPE is one of the Infection Control and Prevention programs included in isolation precautions compiled by Centers for Disease Control and Prevention (CDC) and most important infection control measures is hand hygiene. ${ }^{2}$ Isolation precautions is an infection control precaution prepared by the CDC and should be applied in hospitals and other health services. Isolation precautions are applied to reduce the risk of disease transmission from patient to other patient or to medical worker and evaluate patient. $^{3}$ Isolation precautions is divided into two pillars: standard precaution and transmission based precautions. Standard precautions of infection control and prevention are applied to all patients who have a principle that the blood and fluid of patients potentially transmit the disease, Transmission precautions are in addition to the standard precautions that performed after the type of infection is known. The purpose of Infection Prevention and Control is to help reduce the spread of infections related to health care, by assessment, planning, implementation, and evaluation. 


\section{LITERATURE REVIEW}

Evaluation is a planned activity to know the state of an object by using the instrument and the result is compared with the benchmark to obtain a conclusion (Martha, 2009).4 The purpose of evaluation is to provide material considerations for determining a particular policy, beginning with a systematic data collection process.

Knowledge is the result of knowing and this occurs after a person performs sensing of a particular object. Factors that affect knowledge include: education, mass media, social, cultural, economic, environmental, experience, and age. ${ }^{5}$ Knowledge stages are six levels: know, comprehension, application, analysis, synthesis, evaluation.

Obedience is a human behavior that is obedient to rules, orders, procedures, and discipline. Compliance behavior is temporary because this behavior persists because of supervision. Obedience is a human behavior that is obey to rules, orders, procedures, and discipline. Compliance behavior is temporary because this behavior persists because of supervision. An optimal compliance behavior if the nurse itself considers this behavior is positive. $^{6}$

Factors affecting Compliance consists of intrinsic factors and extrinsic factors. Intrinsic factors include: knowledge, employment, education, and attitude. Extrinsic factors include the completeness of PPE, the comfort of PPE, the regulation of PPE, monitoring the use of PPE. ${ }^{6}$ Factors affecting Compliance consists of intrinsic factors and extrinsic factors. Intrinsic factors include: knowledge, employment, education, and attitude. Extrinsic factors include the completeness of PPE, the comfort of PPE, the regulation of PPE, monitoring the use of PPE.

HAIs (Healthcare-Associated Infections) is a term used for hospital-acquired infections and other health facilities, infections that occur as a result of health interventions. ${ }^{7}$ HAIs are also called nosocomial infections. Precautions and controls HAIs (Healthcare-Associated Infections) need to break one of the chain of transmission including infectious agents, reservoirs, portals of exit, transmission, portal of entery.

The Occupational Safety and Health Administration (OSHA) defines Personal Protective Equipment (PPE) as special clothing or equipment used by employees for the protection of contaminated substances (Prevention Control and Prevention). Types of PPE in the hospital include gloves, masks, google or glasses, gowns or protective gowns, headgear or hats, leg protectors.
The nurse is one of the health workers in the hospital who can have the risk of accidents and occupational diseases. The nurse have daily contacts the patient for a long time of six to eight hours per day, thus exposing the pathogenic microorganisms. Nurses can carry infections from one patient to another.

ICU nurses are different from other parts nurses. The level of work and knowledge of ICU nurses is more complex than that of other hospital nurses, as it is responsible for maintaining patient homeostasis to struggle through near death conditions. ${ }^{8}$ The characteristics of ICU nurses, ie, have a better level of knowledge and skills than other nurses in dealing with critically ill patients. The ICU nurse has at least a BTCLS certificate. ICU services are services provided to patients who are in severe pain and need special care, and require close and ongoing monitoring and immediate action.

\section{RESEARCH METHOD}

This research type is a descriptive survey research using qualitative and quantitative approach, with cross sectional design. Quantitative data was obtained by distributing questionnaires to a number of respondents and qualitative data was taken by observation and interview. ${ }^{9}$

The subject of this research is 20 nurse in Intensive Care Unit (ICU) RSUD Panembahan Senopati Bantul Yogyakarta. Quantitative approach of this research is the distribution of questionnaires using total sampling technique. Qualitative approach in the form of observation is done by total sampling technique and interview is done by purposive sampling technique to get key information.

Quantitative data was obtained by research instrument in the form of questionnaire. Qualitative data were obtained with several research instruments: observation list of compliance of PPE usage, observation sheet of PPE completeness, observation sheet of PPE regulation, check list about socialization or training of Personal Protective Equipment (PPE), and interview guide.

Data analysis is done by coding each question to facilitate the entry of data into the result table, grouping the questions based on the variables studied, entering the questionnaire data, observation, and interviewing into the results table, processing the data into the form of frequency, percentage, median, and standard deviation and displays the results in the form of tables, diagrams, and drawings, and the last is to make the discussion and conclusion of the data obtained. 
RESULT AND DISCUSSION

Table 1. Characteristics of Respondents

Result

\begin{tabular}{|c|c|c|}
\hline Category & Frequency & Percentage \\
\hline \multicolumn{3}{|l|}{ Age } \\
\hline $20-30$ y.o & 5 & $25 \%$ \\
\hline $31-40$ y.o & 8 & $40 \%$ \\
\hline $41-50$ y.o & 5 & $25 \%$ \\
\hline $51-60$ y.o & 2 & $10 \%$ \\
\hline Total & 20 & $100 \%$ \\
\hline \multicolumn{3}{|l|}{ Gender } \\
\hline Male & 5 & $25 \%$ \\
\hline Female & 15 & $75 \%$ \\
\hline Total & 20 & $100 \%$ \\
\hline \multicolumn{3}{|l|}{ Level of Education } \\
\hline D3 & 15 & $75 \%$ \\
\hline D4 & 1 & $5 \%$ \\
\hline S1 & 4 & $20 \%$ \\
\hline Total & 20 & $100 \%$ \\
\hline \multicolumn{3}{|l|}{ Length of Work } \\
\hline $1-5$ years & 4 & $20 \%$ \\
\hline $6-10$ years & 6 & $30 \%$ \\
\hline $11-15$ years & 4 & $20 \%$ \\
\hline $16-20$ years & 2 & $10 \%$ \\
\hline $21-25$ years & 3 & $15 \%$ \\
\hline $26-30$ years & 1 & $5 \%$ \\
\hline Total & 20 & $100 \%$ \\
\hline \multicolumn{3}{|l|}{ Information resourse } \\
\hline Hospital & 11 & $55 \%$ \\
\hline Hospital, internet & 3 & $15 \%$ \\
\hline Hospital, internet, television, etc & 6 & $30 \%$ \\
\hline Total & 20 & $100 \%$ \\
\hline
\end{tabular}

Based on the above table, it can be seen that the nurse in Intensive Care Unit (ICU) of Panembahan Senopati Bantul General Hospital is mostly 31-40 years old (40\%), mostly female (75\%), education level mostly D3 (75\%), Working days are mostly 6-10 years (30\%), and information sources on PPE are mostly obtained from hospitals (55\%).
The knowledge level of the nurse was assessed with a score of $\mathrm{T}$. The result obtained standard deviation value $=$ 1.05; mean $=13.45$; And median $=50$. Furthermore, to categorize the data, the data is processed in the form of a $\mathrm{T}$ score. If the value is greater than or equal to the mean score of $\mathrm{T}(\geq 50)$ it is categorized high knowledge and if smaller than $\mathrm{T}$ score $(<50)$ is categorized low knowledge

Tabel 2. The distribution about Frequency and Percentage of Nurse Knowledge on Use of Personal Protective Equipment (PPE)

\begin{tabular}{ccccc}
\hline No & Category & Frequency & Percentage \\
\hline 1. & Low & 8 & $40 \%$ \\
2. & High & 12 & $60 \%$ \\
& Total & & 20 & $100 \%$ \\
\hline
\end{tabular}

The nurse's compliance level was assessed with a $\mathrm{T}$ score. The results obtained standard deviation values $=0.9$; Mean $=3,6$; And median $=54,25$. If the value is greater than or equal to the mean score $\mathrm{T}(\geq 54.25)$ then it is categorized as obey, and if it is smaller than $\mathrm{T}$ score $(<54,25)$ it is categorized as disobey. 
Table 3. The distributions about Frequency and Percentage of Compliance of Personal Protective Equipment (APD) Nurses Intensive Care Unit (ICU) Panembahan Senopati Bantul Hospital Yogyakarta

\begin{tabular}{lccc}
\hline No & Category & Frequency & Percentage \\
\hline 1 & Obey & 16 & $80 \%$ \\
2 & & 4 & $20 \%$ \\
& DIsobey & 20 & $100 \%$ \\
\hline
\end{tabular}

The following is presented on the availability of Personal Protective Equipment in ICU RSUD Panembahan Senopati Bantul. Based on the following table, it can be seen that googles and hats are not available in the Intensive Care Unit (ICU) of Panembahan Senopati Bantul Hospital

Table 4. Availability of Personal Protective Equipment (PPE) at Intensive Care Unit (ICU) Panembahan Senopati Bantul Hospital Yogyakarta

\begin{tabular}{|c|c|c|c|c|}
\hline \multirow[t]{2}{*}{ No } & \multirow[t]{2}{*}{ Kind of PPE } & \multicolumn{2}{|c|}{ Availability } & \multirow[t]{2}{*}{ Information } \\
\hline & & Yes & No & \\
\hline 1. & Mask & $\sqrt{ }$ & & $\begin{array}{l}\text { The use of masks is limited due to the financial efficiency of } \\
\text { the hospital }\end{array}$ \\
\hline 2. & Gloves & $\sqrt{ }$ & & $\begin{array}{l}\text { The use of gloves is limited due to the financial efficiency of } \\
\text { the hospital }\end{array}$ \\
\hline 3. & Hat & & $\sqrt{ }$ & Not available \\
\hline 4. & Gown / apron & $\sqrt{ }$ & & $\begin{array}{l}\text { Available apron for both nurses and visitors amounted to } 20 \\
\text { pieces. }\end{array}$ \\
\hline 5. & Footwear & $\sqrt{ }$ & & $\begin{array}{l}\text { Available footwear for both nurses and visitors amounted to } \\
\qquad 10 \text { pieces. }\end{array}$ \\
\hline 6. & Googles & & $\sqrt{ }$ & Not available \\
\hline
\end{tabular}

The following table provides the availability of regulations on Personal Protective Equipment in ICU Panembahan Senopati Bantul General Hospital. Based on the following table, guidelines on the use of PPE and

Table 5. Availability of Regulation on Personal Protective Equipment (PPE) in Intensive Care Unit (ICU) Panembahan Senopati Bantul Hospital Yogyakarta.

\begin{tabular}{cccc}
\hline Kind of Regulation & Availability & Information \\
& Yes & No & \\
\hline PPI policy & $\sqrt{ }$ & $\sqrt{ }$ \\
Guideline for the use of PPE & & $\sqrt{ }$ \\
\hline Guide and SOP & & \\
\hline
\end{tabular}

guidelines and SOPs are not available in the Intensive Care Unit (ICU) of Panembahan Senopati Bantul General Hospital. 
The following table presents the history of attending a seminar or training on PPE. Based on the following table, the nurse who has a history of attending the seminar / training APD of $45 \%$, and nurses who do not have a history of attending seminars as many as $55 \%$

Table 6. The History of Attending a Seminar or Training on PPE

\begin{tabular}{ccc}
\hline the History of Attending a Seminar or Training on PPE & Frequency & Information \\
\hline No & 11 & $55 \%$ \\
Yes & 9 & $45 \%$ \\
Total & 20 & $100 \%$ \\
\hline
\end{tabular}

The following results are presented the interviews with informants. The main topic of the interview with the informants is about obstacles and constraints on the use of
PPE, the socialization of PPE, the supervision of PPE, the regulations on PPE, and the recommendations of PPE.

Table 7. Interview with Informan

\begin{tabular}{|c|c|c|}
\hline \multirow[t]{2}{*}{ Category } & \multicolumn{2}{|l|}{ Interview result } \\
\hline & $1^{\text {st }}$ Informan & $2^{\text {nd }}$ Informan \\
\hline Obstacles and constraints on the use of PPE, & $\begin{array}{l}\text { - IPCLN evaluation is still lack } \\
\text { - PPE socialization is still lack } \\
\text { of priority because the } \\
\text { socialization of hand hygiene } \\
\text { is prioritized }\end{array}$ & $\begin{array}{l}\text { - There are no significant obstacles } \\
\text { because the tools are fully available }\end{array}$ \\
\hline the socialization of PPE & $\begin{array}{l}\text { - PPI training is one of five } \\
\text { compulsory training in the } \\
\text { hospital, including effective } \\
\text { communication and patient } \\
\text { safety }\end{array}$ & $\begin{array}{l}\text { The nursing team is almost } 50 \% \\
\text { following the PPE socialization }\end{array}$ \\
\hline the supervision of PPE & $\begin{array}{l}\text { - There is a separate committee } \\
\text { of PPI committees supported by } \\
\text { IPCLN }\end{array}$ & $\begin{array}{l}\text { - At first there was an observer from } \\
\text { IPCLN, but now no longer exists }\end{array}$ \\
\hline the regulations on PPE & $\begin{array}{l}\text { - There is a PPI guide in each } \\
\text { hospital unit }\end{array}$ & Regulation is complete \\
\hline the recommendations of PPE & $\begin{array}{l}\text { - There should be control and } \\
\text { evaluation of the use of PPE } \\
\text { each month }\end{array}$ & $\begin{array}{l}\text { - There is no. All the tools are } \\
\text { sufficient and the team of nurses } \\
\text { remind each other in the use of PPE }\end{array}$ \\
\hline
\end{tabular}

\section{Discussion}

\section{Nursing Knowledge Level on Use of Personal Protective Equipment (PPE)}

Based on the results of the study, as many as 12 nurses (60\%) had a high level of knowledge about PPE and 8 nurses $(40 \%)$ had low knowledge about PPE. This shows that the total knowledge of the respondents including knowledge is high. Knowledge is a process of not knowing to be know. This occurs after a person performs sensing through sight, hearing, smell, taste, and touching over a particular object. Another opinion also reveals that knowledge is information that has been combined with the understanding and potential for action, which is then embedded in the minds of a person. Much of a person's knowledge is gained through education, the experiences of others, the media, and the environment. ${ }^{10}$

\section{Nurses Compliance Level on Use of Personal Protective Equipment (PPE)}

Based on the results of the study, 16 nurses (80\%) adhered to the use of Personal Protective Equipment (APD) and 4 nurses $(20 \%)$ did not adhere to the use of Personal Protective Equipment (PPE). This shows that the Intensive Care Unit (ICU) nurses adhere to the use of PPE. Knowledge is a very important factor for the formation of a person's behavior, if a person has a lack of knowledge about 
the potential or source of hazards that exist in the work environment, then the individual will tend to make a wrong decision, in this case the compliance behavior of use of PPE. The results of this study indicate that knowledge is one of the predisposing factors that encourage or inhibit individuals to behave obediently (in terms of use of PPE).

\section{CONCLUSION}

The total of 12 nurses $(60 \%)$ have a high level of knowledge on the PPE and 8 nurses (40\%) have low knowledge level on PPE. The total of 16 nurses $(80 \%)$ Obey the use of Personal Protective Equipment (APD) and 4 nurses (20\%) Uncompromising in the use of Personal Protective Equipment (PPE). The majority of Intensive Care Unit (ICU) of Panembahan Senopati Bantul Hospital $55 \%$ have not attended training and seminar on Personal Protective Equipment (PPE). Completeness of Personal Protective Equipment (PPE) in the form of hat and googles still not available. There are no guidelines for the use of PPE and guidelines and SOPs.

Based on the conclusions of the study, suggestions may be given as follows: Involve nurses in training programs or seminars on PPE regularly to remind and refresh nurse knowledge about the importance of using Personal Protective Equipment (PPE), Complete personal protective equipment according to $\mathrm{MOH}$ standards gradually, both PPE is often used or rarely used. So when there are medical actions that require PPE, nurses do not have to bother looking everywhere, for example googles and hats, Complete the rules on PPE such as Guidelines on the Use of PPE and Guidelines and SOPs, There needs to be regular and continuous evaluation of the use of Personal Protective Equipment (PPE).

\section{REFERECE}

1. Elizabeth L. Daugherty, Trish M. Perl. Dale M. Needham. Lewis Rubinson, Andrew Bilderback. MS; Cynthia S. Rand. 2009. The use of personal protective equipment for control of influenza among critical care clinicians: A survey study. Continuing Medical Education Article. Vol. 37, No. 4

2. Emine Alp, Hakan Leblebicioglu, Mehmet Doganay and Andreas Voss. 2011. Infection control practice in countries with limited resources. Alp et al. Annals of Clinical Microbiology and Antimicrobials 2011, 10:36.

3. Hany Girgis Eskander, Warda Youssef Mohammed Morsy, Hanaa Ali Ahmed Elfeky. 2013. Intensive Care Nurses' Knowledge \& Practices regarding
Infection Control Standard Precautions at a Selected Egyptian Cancer Hospital. Journal of Education and Practice. Vol.4, No.19.

4. Martha, (2009), Company Profile Uncluster.com (pdf), P.T Pituari Inspira Semesta, Bandung

5. Kelemua Gulilat. Gebeyaw Tiruneh. 2014. Assessment of knowledge, attitude and practice of health care workers on infection prevention in health institution Bahir Dar city administration. 2014. Science Journal of Public Health 2014; 2(5): 384-393.

6. Evaldiana, (2013). Kepatuhan Perawat terhadap Penggunaan Alat Pelindung Diri (APD) dalam Menangani Pasien TB Paru Di Rumah Sakit Paru dr. Ario Wirawan Salatiga. Skripsi. Universitas Kristen Satya Wacana Salatiga. Diakses pada 6 Maret 2016, dari:

http://repository.uksw.edu/handle/123456789/6706.

7. Robyn Mitchell, Virginia Roth, Denise Gravel, George Astrakianakis, Elizabeth Bryce, Sarah Forgie, et al.,2013, 'Are health care workers protected? An observational study of selection and removal of personal protective equipment in Canadian acute care hospitals', American Journal of Infection Control, vol. 41, no 3, pp 240-244

8. Hudak \& Gallo (2010). Keperawatan Kritis Edisi 6. Jakarta; EGC

9. Marlia Duarte Valim, Maria H Palucci Marziale, Miguel Richart Martınez and Angela Sanjuan Quiles. 2013. Instruments for evaluating compliance with infection control practices and factors that affect it: an integrative review. Journal of Clinical Nursing, doi: 10.1111/jocn. 12316 .

10. Notoatmodjo. 2007. Promosi Kesehatan dan Ilmu Perilaku. Jakarta : PT. Rineka Cipta.

11. Siburian, Apriani 2012. 'Gambaran Penggunaan Alat Pelindung Diri (APD) terhadap Keselamatan Pasien Kerja Perawat IGD RSUD Pasar Rebo tahun 2012'. Skripsi. Fakultas Ilmu Keperawatan Univ Indonesia

12. Banda, Irfan. 2015. 'Hubungan Perilaku Perawat dengan Kepatuhan Menggunakan Alat Pelindung Diri (APD) Sesuai Standard Operating Procedure (SOP) di Ruang Rawat Inap Badan Layanan Umum Daerah (BLUD) Rumah Sakit Konawe'. Skripsi. Fakultas Kesehatan Masyarakat Universitas Haluleo.

13. Budiman dan Riyanto (2013)Kapita Selekta Kuesioner Pengetahuan dan Sikap dalam Penelitan Kesehatan.Jakarta : Salemba Medika

14. Demak DLK. 2013. 'Analisis Penyebab Perilaku Aman Bekerja pada Perawat di RS Islam Ashshobirin 
Tangerang Selatan Tahun 2013.' Skripsi. UIN Syarif Hidayatullah Jakarta.

15. Depkes RI (2010)Sistem Kesehatan Nasional. Jakarta

16. Dewi, Igapa (2010)"Hubungan antara quick of blood (Qb) dengan edukasi hemodiaisis pada pasien yang menjalani terapi hemodialisis di ruang HD RSU Daerah TahananB ali”. Tesis . Univesitas Indonesia, Depok.

17. Dinkes (2005) Pedoman Unit Gawat Darurat. Yogyakarta : Dinkes Propinsi DIY

18. Elizabeth L. Beam, Shawn G. Gibbs,Kathleen C. Boulter,Marcia E. Beckerdite,Philip W. Smith, 2011, 'A method for evaluating health care workers' personal protective equipment technique' American Journal of Infections Control, vol. 39, no. 5, pp 415420

19. Farida, A (2010) "Pengalaman klien hemodialisis terhadap kualitas hidup dalam konteks asuhan keperawatan di RSUP Fatmawati Jakarta", Universitas Indonesia, Tesis, Depok

20. Ganczak\&Z. Szych, 2007, 'Surgical nurses and compliance with personal protective equipment',Journal of Hospital Infection, vol. 66, no. 4, pp 346-35

21. Ghozali (2009)Pengertian Uji Validitas dan Uji Reliabilitas

22. Ivana, A, dkk. 2014. 'Analisa Komitmen Manajemen Rumah Sakit (RS) terhadap Keselamatan dan Kesehatan Kerja (K3) pada RS Prima Medika Pemalang'. Jurnal Kesehatan volume 2, Nomer 1, Januari 2014

23. Kathryn Nichol, Allison McGeer, Philip Bigelow, Linda O'Brien-Pallas, James Scott, D. Linn Holness, 2013, 'Behind the mask: Determinants of nurse's adherence to facial protective equipment', American Journal of Infection Control,vol 41, no 1, pp 8-13

24. Kusnanto (2003)PengertianPerawat dan Keperawatan. Jakarta

25. Ningsih, Shely. S.R (2014).' Gambaran Perilaku Perawat dalam Penggunaan Alat Pelindung Diri di Ruang Rawat Inap Rumah Sakit Umum Daerah Kota Bandung.' Thesis. Universitas Pendidikan Indonesia diakses pada 01 Juni 2017, dari :http//repository.upi.edu/15871/.

26. Notoatmodjo, S (2007)Promosi Kesehatan dan Ilmu Perilaku. Jakarta : Rhineka Cipta

27. Notoatmodjo, S (2012)Metodologi Penelitian Kesehatan. Jakarta : Rhineka Cipta

28. Nur'aini (2014)Pengertian Perawat 2014.Jakarta

29. Nursalam (2007)Manajemen Keperawatan, Aplikasi, dan Praktik Keperawatan Profesional, Edisi 2. Jakarta : Salemba Medika

30. Nursalam. 2007. Manajemen Keperawatan Edisi 2. Jakarta : Salemba Medika

31. Rahaju P, 2011.' Analisis Faktor Pemakaian Alat Pelindung Diri (APD) pada Petugas di Unit Laboratorium.' Skripsi. Universitas Tanjung Karang

32. Rahel Mathews, Jack K. Leiss, Jennifer T. Lyden, Sara Sousa,Jennifer M. Ratcliffe,Janine Jagger, 2008, 'Provision and use of personal protective equipment and safety devices in the National Study to Prevent Blood Exposure in Paramedics', American Journal of Infection Control, vol. 36, no. 10,pp. 743-749

33. Rajeswari, RR \& Sivamani, L (2010)Nursing Care Dyalisis, Laporan Artikel, Geneverment General Hospital

34. Riwidigdo (2010)Statistik Penelitian Kesehatan. Yogyakarta : Pustaka Rihanna

35. Riyanto, Agus (2011)Aplikasi Medodologi Penelitian Kesehatan.Yogyakarta : Nuha Medika

36. Sahara A, 2011. 'Faktor - faktor yang Berhubungan dengan Kepatuhan Perawat dan Bidan dalam Penerapan Kewaspadaan Universal / Kewaspadaan Standar di Rumah Sakit Palang Merah Indonesia Bogor tahun 2011.' Skripsi. Fakultas Ilmu Keperawatan Univeritas Indonesia

37. Sekaran (2007)Metodologi Penelitian untuk Bisnis. Jakarta : Salemba Empat

38. Sugiyono (2010)Memahami Penelitian Kualitatif. Bandung : Alfabeta

39. Sugiyono (2013)Metode Penelitian Manajemen. Bandung : Alfabeta

40. WHO (2010)Health Care Associated Infection[internet]. Geneva : WHO Press [Diakses pada 6 Maret 2017] 